\title{
Clinicopathological Conferences: a testimonial
}

\author{
Luiz Otávio Savassi Rochaa
}

Rocha LOS. Clinicopathological Conferences: a testimonial [editorial]. Autopsy Case Rep [Internet]. 2013; 3(3): 1-4. http://dx.doi.org/10.4322/acr.2013.022

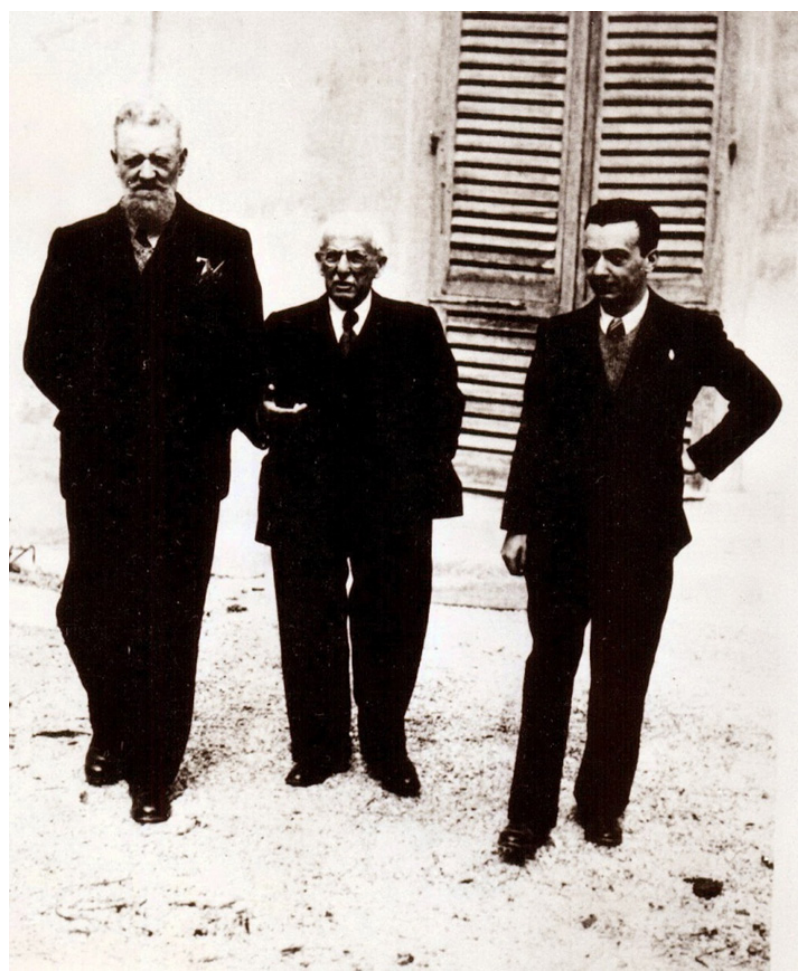

E. E. Franco, Cesare Sacerdotti and Luigi Bogliolo: "I tre sofi". (Pisa, March 1938)

Picture - Personal archive of the author.

The origins of my visceral connection with Clinicopathological Conferences date back to April 18,1908 , the date of birth in Sassari, on the island of Sardinia, of the Italian pathologist Luigi Bogliolo, who graduated from the local Faculty of Medicine in 1930.

At medical school, from 1927 to 1930 , Bogliolo was teaching assistant of Pathology, under the guidance of the very demanding Professor Enrico Emilio Franco, who was a source of inspiration for him throughout his life. Franco, an Italian of Jewish origin, graduated in 1906 from the University of Padua and, therefore, was a disciple of the School of Giovanni Battista Morgagni, the "Father of Pathological Anatomy". In the two-year period 1931-1932, Bogliolo was a volunteer assistant at the Institute of Pathological Anatomy and Histology of the University of Sassari, directed by Franco. In late 1932, he moved along with his master to the University of Bari, becoming a staff assistant of the Pathological Anatomy Department. In December 1936, following the footsteps of Franco once more, he moved to the University of Pisa, as Deputy

\footnotetext{
a Faculdade de Medicina - Universidade Federal de Minas Gerais, Belo Horizonte/MG - Brazil.
} 
Director of the Institute of Pathological Anatomy and Histology, where he remained until March 1939. In 1938 , in Pisa, the young pathologist earned the title of full professor and, that same year, married Geula Bennoun, a medical student, also of Jewish origin, born in Jaffa, the twin city of Tel Aviv.

During the time they worked in Pisa, Bogliolo and Franco were linked, by friendship and profession, to the Chairman of General Pathology, Professor Cesare Sacerdotti, to whom they referred respectfully as "Il professore". Sacerdotti was a disciple of Camillo Golgi, Nobel Prize winner in Physiology or Medicine in 1906, and Giulio Bizzozero who, in turn, was a disciple of Rudolf Virchow, the "Father of Cellular Pathology". Bizzozero gained notoriety for his discovery of platelets and their role in hemostasis and, more recently, for his discovery of spiral bacteria in the stomach of dogs, the first step for the identification of the species Helicobacter pylori in the human stomach. As evidence of the prestige they enjoyed in the University of Pisa, the three friends - Bogliolo, Franco, and Sacerdotti - were named "I tre sofi," or "The three wise men".

Among Bogliolo's publications during his academic life in Italy, special mention should be made of his induction of sarcomas by injection of the radiological contrast medium Thorotrast (radioactive thorium dioxide) as reported in Mus musculus, var. alba (1937) and in Mus norvegicus (1938). ${ }^{1,2}$ Despite this experimental evidence, Thorotrast continued to be used until the mid-1950s in prestigious institutions - including Massachusetts General Hospital, the Lahey Clinic, and the University of Michigan Hospital - leading to the death of hundreds of patients from malignant neoplasms, especially hepatic hemangioendotheliosarcoma and cholangiocarcinoma.

Dismissed from the University of Pisa in January 1939, amid a wave of anti-Semitism that plagued his homeland, Franco was forced to exile in Jerusalem, where he died in 1950 at 68 years of age. In March 1939, Bogliolo was fired from the University of Pisa due to his antifascist position, worsened by his close relationship with Professor Franco and Geula Bennoun, and he was forced to leave his home country as well. After spending a few months in Belgium, Bogliolo, along with his wife, headed to Brazil, arriving in Rio de Janeiro on January 5, 1940. In January 1941 , after facing serious difficulties, he became the chief pathologist, at the National Faculty of Medicine (now Faculty of Medicine, Universidade Federal do Rio de Janeiro [UFRJ]), of the Internal Medicine Service directed by the renowned clinician, Professor Heitor Annes Dias, nicknamed the "Brazilian Jiménez Díaz".

Perfectly harmonized with Annes Dias, Bogliolo boosted the Clinicopathological Conferences at that institution. Inspired by the memorable lessons of Master Franco, he conducted the autopsies of the cases that were presented in those sessions. Therefore, after the clinical features had been discussed, the diagnostic hypotheses had been formulated, and the possible reasons for death had been considered, he was in charge of the autopsy report. Furthermore, at the end of the session, he used to perform the great synthesis - the epicrisis - correlating the post mortem findings with those observed intra vitam.

With the untimely death of Annes Dias in November 1943, Alfredo Balena, Bogliolo's compatriot and Director of the Faculty of Medicine, University of Minas Gerais (now Faculty of Medicine, Universidade Federal de Minas Gerais [UFMG]), invited him to become the Head of the Department of Pathological Anatomy of the institution Balena helped to found in 1911. In his new home, Bogliolo continued to favor Clinicopathological Conferences from 1944 until his mandatory retirement in 1978.

In the autopsy room - considered by him a "sacred temple" - Bogliolo demanded that the cadaver be treated with absolute respect, incorporating the message contained in the famous Latin maxim "Taceant colloquia. Effugiat risus. Hic locus est ubi mors gaudet succurrěre vitae.", according to which, in an environment where death delights to help the living, there should be no talking or laughing.

During my time at the medical school of the UFMG, I was invited by Professor Bogliolo to serve as a teaching assistant at the Department of Pathological Anatomy and Forensic Medicine, headed by the unforgettable master. For four years after graduating, I remained linked to this department. During this period, I had the opportunity to perform many autopsies, cementing my belief in the inestimable pedagogical value of clinicopathological correlation exercises.

From May 1995, as Professor of Internal Medicine, I assumed the responsibility for coordinating the Clinicopathological Conferences of the Hospital das Clínicas - UFMG, attended by graduate students, medical residents, professors, and other interested parties. Between May 1995 and June 2013, I personally managed 223 Clinicopathological Conferences. At the $116^{\text {th }}$ Clinicopathological Conference, a case of mucopolysaccharidosis type II (Hunter syndrome) 
was discussed. In this case, the patient presented respiratory failure and cardiac involvement, with the finding of apical aneurysm of the left ventricle very similar to the characteristic "vorticilar lesion" of chronic Chagas' cardiomyopathy, considered by many to be pathognomonic of this condition. At the invitation of Dr. Alfredo José Mansur, Editor of the section Clinicopathological Session of the journal Arquivos Brasileiros de Cardiologia, this case was published in the July 2006 issue. ${ }^{3}$ At the $215^{\text {th }}$ Clinicopathological Conference, a case of shock due to a clinically unsuspected left adrenal bulky pheochromocytoma with areas of hemorrhage and massive central necrosis was presented. This case was published in the journal Autopsy and Case Reports in 2012. ${ }^{4}$

In 1992 and 2010, I had two books published, respectively Vida e Obra de Luigi Bogliolo (Life and Work of Luigi Bogliolo), ${ }^{5}$ dedicated to the memory of our missing master, and Sessões Anatomoclínicas: valor pedagógico lato sensu (Anatomoclinical Sessions: pedagogical value lato sensu). ${ }^{6}$ In the latter, prefaced by $\mathrm{Dr}$. Alfredo José Mansur, I sought to stimulate the dialogue with other disciplines, such as Biology, Medical Education, Public Health, Forensic Medicine, Psychology, History of Medicine, and even Literature - hence the reason for inclusion of the expression "lato sensu" in the title of the book.

From April 2007, along with Professor Geraldo Brasileiro Filho, the current editor of the textbook Bogliolo: Patologia, ${ }^{7}$ I have been participating in the interactive sessions of Telepathology (38 sessions until April 2013), which feature videoconferences in real time of autopsies performed at the Coroner's Service of the Faculty of Medicine of University of São Paulo (USP). In addition, since September 2012, at the invitation of Dr. Fernando Peixoto Ferraz de Campos and Professor Maria Cláudia Nogueira Zerbini, I have been participating along with teachers of UFMG (including Professor Geraldo Brasileiro Filho) and USP in the interactive meetings, which are also transmitted by videoconference, designed to discuss cases of autopsies performed at the Hospital Universitário - USP (seven meetings through to June 2013).

Despite their extraordinary heuristic value, Clinicopathological Conferences have become, in most academic institutions, increasingly rare because of the large reduction in the number of autopsies. This is due, in part, to the overconfidence of modern physicians; having access to highly sophisticated diagnostic technologies, they consider themselves immune to error. Nevertheless, contrary to expectations, the incidence of diagnostic errors detected by autopsy remains significant. A JAMA editorial by Dr. George D. Lundberg explains in a clear, compelling way, why these discrepancies are still prevalent today: ${ }^{8}$

In fact, there is still a giant gap between what hightech diagnostic medicine can do in theory in ideal circumstances (very much, very well) and what hightech diagnostic medicine does do in practice in real-life circumstances (not nearly so well), when human beings have to decide what, where, when, how, and why to use it. The gap becomes especially obvious when one looks at patients sick unto death.

However, my continuing high regard for the Clinicopathological Conferences lies not only in the confrontation between clinical and pathological diagnoses, a setting in which not only the clinician but also the pathologist may equivocate. The latter, quite often, does not deal with pure, concrete, and objective "facts" in nature, but with complex situations, involving often debatable interpretation. Therefore, without losing sight of the importance of the "product" represented by the report of the autopsy findings, one should focus on the "process", which is marked by the exercise of clinical judgment, the refinement of the critical spirit, and the cultivation of systematic doubt.

Accordingly, by way of conclusion, it is worth evoking the words of João Guimarães Rosa in The devil to pay in the backlands (Grande Sertão: Veredas): ${ }^{9}$

I mean, the truth is not in the setting out nor in the arriving: it comes to us in the middle of the journey.

\section{REFERENCES}

1. Bogliolo L. Produzione col thorotrast di un sarcoma fusocellulare fascicolato nel Mus musculus var. alba. Pathologica. 1937;29:372-6. Italian.

2. Bogliolo L. Sopra i blastomi sperimentale da ossido di torio. II ${ }^{\mathrm{a}}$ Nota. Pathologica. 1938;30:422-30. Italian.

3. Rocha LOS, Quirino BEG, Melo FHC, et al. Progressive respiratory failure in a 33 year-old man with heart disease and remarkable somatic dysmorphism. Clinicopathological session. Case 3/2006. Arq Bras Cardiol. 2006;87:61-9. Portuguese. PMid:16906272.

4. Araújo SA, Carmo PAS, Paulino E Jr, et al. Pheochromocytoma-induced shock: a case report. Autopsy Case Rep [Internet]. 2012;2(3):21-30. http://dx.doi. org/10.4322/acr.2012.022 
5. Rocha LOS. Vida e obra de Luigi Bogliolo. Belo Horizonte: Fundação Cultural de Belo Horizonte; 1992. Portuguese.

6. Rocha LOS. Sessões Anatomoclínicas: valor pedagógico lato sensu. Belo Horizonte: Coopmed; 2010. Portuguese.

7. Brasileiro Filho G, editor. Bogliolo Patologia. 8. ed. Rio de Janeiro: Guanabara Koogan; 2011. Portuguese.
8. Lundberg GD. Low-tech autopsies in the era of high-tech medicine: continued value for quality assurance and patient safety [editorial]. JAMA. 1998;280:1273-4. http://dx.doi. org/10.1001/jama.280.14.1273

9. Rosa JG. The devil to pay in the backlands. James L. Taylor, Harriet de Onís, translators. New York: Alfred A. Knopf; 1963. p. 52.

Correspondence: Luiz Otávio Savassi Rocha

Faculdade de Medicina - Universidade Federal de Minas Gerais, Belo Horizonte/MG - Brazil

E-mail: savassi@estaminas.com.br 